\title{
Effect of Vacuum Packaging on Chewiness of Kradi Cheese Stored at Different Temperatures
}

\author{
Hilal Ahmad Punoo \\ Department of Food Science and Technology, University of Kashmir, Srinagar, Jammu and Kashmir, India
}

Email address:

hilalpunoo@gmail.com

\section{To cite this article:}

Hilal Ahmad Punoo. Effect of Vacuum Packaging on Chewiness of Kradi Cheese Stored at Different Temperatures. American Journal of Health Research. Vol. 9, No. 2, 2021, pp. 46-49. doi: 10.11648/j.ajhr.20210902.13

Received: April 3April 3, 2021; Accepted: April 23, 2021; Published: May 14, 2021

\begin{abstract}
In this study effect of vacuum packaging and storage time on chewiness of kradi cheese stored at $25^{\circ} \mathrm{C}, 5^{\circ} \mathrm{C}$ and $20^{\circ} \mathrm{C}$ for different periods was studied. It was observed that both vacuum packaging and storage time had an influence on chewiness of cheese. At $25^{\circ} \mathrm{C}$ storage temperature initial chewiness of $52.41 \mathrm{~N} . \mathrm{mm}$ in vacuum packed samples decreased to 33.24 N.mm on $20^{\text {th }}$ day whereas in normal packed samples it decreased to 23.11 N.mm on $15^{\text {th }}$ day of storage. At $5^{\circ} \mathrm{C}$ of storage temperature, the initial chewiness of $52.41 \mathrm{~N} . \mathrm{mm}$ in vacuum packed samples decreased to $17.21 \mathrm{~N} . \mathrm{mm}$ till $16^{\text {th }}$ week of storage while in normal packed samples it decreased to $17.45 \mathrm{~N} . \mathrm{mm}$ till $14^{\text {th }}$ week of storage. At $-20^{\circ} \mathrm{C}$ decrease in chewiness was very slow as compared to refrigeration temperature. At $-20^{\circ} \mathrm{C}$ chewiness of kradi cheese was better maintained than at refrigeration temperature of $5^{\circ} \mathrm{C}$ in vacuum packaging and the product can be stored for long time at $-20^{\circ} \mathrm{C}$ in vacuum packaging. Chewiness decreased more in normal packed samples than vacuum packed samples. The vacuum packaging retarded chewiness changes in comparison to normal packaging. Vacuum packaging of kradi cheese exhibited possibility of preserving kradi cheese for longer time as compared to normal packaging.
\end{abstract}

Keywords: Kradi Cheese, Vacuum Storage, Temperature, Chewiness

\section{Introduction}

Texture refers to those qualities of a food that can be felt with the fingers, tongue, palate, or teeth. Foods have different textures, such as crisp, crunchy, hard, tender, chewy and sticky [5]. The term 'food texture' embraces a large number of textural characteristics which are identified and evaluated by the consumer in a well-defined order during mastication. Consumer preference is important to the food manufacturer, who wants to gain as wide a share of the market for the product as possible [7]. Measuring texture of foods involves use of physical techniques to objectively evaluate food quality, such as texture analysis. Instrumental evaluation of texture is performed with a texture analyzer which involves measuring the response of a food when it is subjected to a force, such as cutting, shearing, chewing or compressing [6]. A vast range of food texture fixtures are available that provide this range of mechanical texture analysis possibilities. Such tests are essential in the food industry for measuring texture, especially for routine quality control of food products. Texture analyzers are used to measure many properties, such as hardness, chewiness, brittleness, spreadability, adhesiveness, tensile strength, extensibility, etc., on a vast range of products. Texture is also an index of food quality. Texture has a role in deciding the quality of cheese [8]. Quality is difficult to define precisely, but it refers to the degree of excellence of a food and includes all the characteristics of a food that are significant and that make the food acceptable. Chewiness is the time required to masticate sample of cheese at a constant rate of force application so as to reduce it to a consistency that makes it easy for swallowing.

The texture of food can change as it is stored for various reasons. Cheese can become hard and stale on storage and this would be considered deterioration in its textural quality. The textural degradation of cheese is not desired during storage. Such textural changes induced during storage can alter the quality of product [4]. Kradi cheese is one of the ethnic cheese of Jammu Kashmir having unique textural characteristics. Vacuum packaging can reduce textural 
deterioration in cheese as compared to ordinary packaging. The replacement of air with vacuum in vacuum packaging can either increase or decrease chewiness changes during storage of kradi cheese. The vacuum packaging can be a way of preserving textural quality of kradi cheese. Vacuum packaging can preserve the soft texture of cheese [17]. The sale of kradi cheese is increasing annually and the product is stored at refrigeration in normal packaging. Kradi cheese is usually stored at different temperatures by the retailer for sale, there is need to study effect of packaging conditions on chewiness of product with an aim to improve the overall quality of the product so that the product remains acceptable to consumers with respect to quality. Physico chemical, microbiological, microstructural properties, descriptive sensory analysis and chemical changes during storage of kradi cheese have been reported [9, 10, 13, 12]. Since chewiness is important textural quality judged by consumer at the time of purchasing the kradi cheese, however no studies have been reported with respect to changes in chewiness of kradi cheese during storage. It would be immensely interesting, therefore, to know as how packaging conditions influence the chewiness properties of Kradi. Therefore present study was aimed at assessment of changes in chewiness of kradi cheese throughout its storage at different periods at different temperatures under vacuum and non vacuum conditions.

\section{Materials and Methods}

\subsection{Preparation of Kradi Cheese}

Kradi cheese was made as per the method described [9]. The fresh product was packed in multilayer laminates under vacuum and normal conditions and stored at three different temperatures, $25^{\circ} \mathrm{C}, 5^{\circ} \mathrm{C}$ and $-20^{\circ} \mathrm{C}$. The products stored were evaluated at one day interval at $25^{\circ} \mathrm{C}$, on weekly interval at $5^{\circ} \mathrm{C}$ and on monthly interval at $-20^{\circ} \mathrm{C}$ to monitor changes in chewiness of textural properties.

\subsection{Texture Profile Analysis (TPA)}

The textural profile of kradi cheese was performed using TAXT-2i (Stable Micro System, UK) fitted with a $25 \mathrm{~kg}$ load cell. The cubes of kradi cheese samples $1 \times 1 \times 1 \mathrm{~cm}^{2}$ were subjected to mono-axial compression up to $80 \%$ of its original height on the textural analyzer. The TPA was carried out at $25^{\circ} \mathrm{C}$ after tempering the sample for $1 \mathrm{~h}$ at this temperature. The textural parameter of chewiness was determined according to the method [2].

\subsection{Statistical Analysis}

The data obtained during the present investigation was compared by one-way analysis of variance (ANOVA) with the application of SYSTAT software, version 6.0.1 copyright C 1996, SPSS INC and also by Microsoft ${ }^{\circledR}$ Excel StatPro $^{\text {TM }}$ (Palaside Corporation, Newfield, NY). Significant difference $(\mathrm{p}<0.05)$ among treatments were detected using Duncan's multiple range tests.

\section{Results and Discussion}

The chewiness of Kradi samples exhibited a decreasing trend (Table 1) throughout the entire storage period in all the samples packed in two types of atmospheres and stored at different temperatures for different periods. The initial value of chewiness $52.41 \mathrm{~N} . \mathrm{mm}$ in normal packed samples decreased to $23.11 \mathrm{~N} . \mathrm{mm}$ on $15^{\text {th }}$ day of storage while in vacuum packed it decreased to $33.24 \mathrm{~N} . \mathrm{mm}$ on $20^{\text {th }}$ day at $25^{\circ} \mathrm{C}$. This indicates that decrease in chewiness was slow under vacuum conditions as compared to normal conditions. The chewiness measurement at $25^{\circ} \mathrm{C}$ was stopped after $15^{\text {th }}$ day of storage in normal packaging as the samples were not sensorialy accepted while samples packed under vacuum chewiness measurement continued till $20^{\text {th }}$ day of storage. ANOVA revealed that effect of packages and storage periods was highly significant $(\mathrm{p} \leq 0.01)$ on the chewiness of samples stored at $25^{\circ} \mathrm{C}$. Soy paneer prepared from admixtures of skim cow milk and soymilk stored at $25^{\circ} \mathrm{C}$ for fifteen days showed decrease in chewiness [11]. Sliced cheese stored at $25^{\circ} \mathrm{C}$ during storage showed decrease in chewiness [14]. At $5^{\circ} \mathrm{C}$ of storage temperature, the initial chewiness 52.41 N.mm in normal packed samples decreased to 17.45 N.mm after $14^{\text {th }}$ week of storage while in vacuum packed samples it decreased to 17.21 N.mm after $16^{\text {th }}$ week of storage. The chewiness measurement at $5^{\circ} \mathrm{C}$ was stopped after $14^{\text {th }}$ week of storage in normal packaging as the samples were not sensorialy accepted while samples packed under vacuum were sensorialy acceptable till $16^{\text {th }}$ week of storage. Sliced cheese stored at $4^{\circ} \mathrm{C}$ during storage showed decrease in chewiness [14]. White soft cheese made from buffalo and cow milk mixtures stored at $4{ }^{\circ} \mathrm{C}$ for three month showed decrease in chewiness [3]. Mozzarella cheese stored in different atmospheres at $7^{\circ} \mathrm{C}$ reported decrease in chewiness of entire storage period [1]. Soy paneer prepared from admixtures of skim cow milk and soymilk stored at $5^{\circ} \mathrm{C}$ for ninety days reported decrease in chewiness [11]. Paneer showed decrease in chewiness stored at $4{ }^{\circ} \mathrm{C}$ for 7 days [15]. In soft caprine milk cheese chewiness was more in six month old cheese as compared to three month old cheese stored at $4^{\circ} \mathrm{C}$ [16]. Softening was observed in manchego style cheese during ripening for 180 days at $10^{\circ} \mathrm{C}$ [18]. ANOVA (Table 2) revealed that type of packages and storage periods had highly significant $(p \leq 0.01)$ effect on the chewiness of samples stored at $5^{\circ} \mathrm{C}$. At $-20^{\circ} \mathrm{C}$ of storage temperature, the initial chewiness 52.41 N.mm in normal packed samples decreased to 35.1 N.mm after 6 months of storage while in vacuum packed samples it decreased to 36.52 N.mm after 6 months of storage. This indicates that decrease in chewiness was slow at deep freeze as compared to refrigeration temperature. Soy paneer prepared from admixtures of skim cow milk and soymilk stored at $-20^{\circ} \mathrm{C}$ for five months reported decrease in chewiness [11]. In soft caprine milk cheese, cheeses stored for two days at $4^{\circ} \mathrm{C}$ were less chewy than cheeses stored at $20^{\circ} \mathrm{C}$ for three and six month [16]. ANOVA (Table 2) revealed that packages and storage periods had highly significant $(p \leq 0.01)$ effect of on the chewiness of samples 
stored at $-20^{\circ} \mathrm{C}$. Since chewiness values were maintained for of storage in kradi cheese, so this gives rich mouth feel and longer periods under vacuum packaging at all temperatures increases the taste of kradi cheese.

Table 1. Effect of vacuum packaging on textural characteristics of Kradi cheese stored at $25^{\circ} \mathrm{C}, 5^{\circ} \mathrm{C}$ and $-20^{\circ} \mathrm{C}$.

\begin{tabular}{|c|c|c|c|c|c|c|c|c|}
\hline \multirow{3}{*}{$\begin{array}{l}\text { Period of } \\
\text { storage } \\
\text { (Days) }\end{array}$} & \multicolumn{2}{|c|}{ Temperature of storage $\left(25^{\circ} \mathrm{C}\right)$} & \multirow{3}{*}{$\begin{array}{l}\text { Period of } \\
\text { storage } \\
\text { (weeks) }\end{array}$} & \multirow{2}{*}{\multicolumn{2}{|c|}{$\begin{array}{l}\text { Temperature of storage }\left(5^{\circ} \mathrm{C}\right) \\
\text { chewiness }\end{array}$}} & \multirow{3}{*}{$\begin{array}{l}\text { Period of } \\
\text { storage } \\
\text { (months) }\end{array}$} & \multirow{2}{*}{\multicolumn{2}{|c|}{$\begin{array}{l}\text { Temperature of storage }\left(-20^{\circ} \mathrm{C}\right) \\
\text { chewiness }\end{array}$}} \\
\hline & \multicolumn{2}{|c|}{ chewiness } & & & & & & \\
\hline & VP & NP & & VP & NP & & VP & NP \\
\hline 1 & 52.41 & 52.41 & 1 & 52.41 & 52.41 & 1 & 52.41 & 52.41 \\
\hline 2 & 51.24 & 50.21 & 2 & 51.12 & 49.41 & 2 & 50.41 & 48.63 \\
\hline 3 & 50.24 & 47.31 & 3 & 48.54 & 47.41 & 3 & 47.21 & 45.12 \\
\hline 4 & 49.63 & 45.85 & 4 & 45.74 & 44.14 & 4 & 44.21 & 42.13 \\
\hline 5 & 48.25 & 43.56 & 5 & 41.42 & 41.25 & 5 & 40.25 & 38.41 \\
\hline 7 & 46.27 & 39.55 & 7 & 34.15 & 34.15 & & & \\
\hline 8 & 45.41 & 37.42 & 8 & 31.12 & 29.11 & & & \\
\hline 9 & 44.41 & 35.41 & 9 & 28.45 & 27.15 & & & \\
\hline 10 & 43.25 & 33.21 & 10 & 26.41 & 25.41 & & & \\
\hline 11 & 42.58 & 31.57 & 11 & 25.11 & 23.22 & & & \\
\hline 12 & 41.52 & 29.65 & 12 & 23.98 & 21.12 & & & \\
\hline 13 & 40.35 & 27.65 & 13 & 22.12 & 19.25 & & & \\
\hline 16 & 37.54 & - & 16 & 17.21 & - & & & \\
\hline 17 & 36.54 & - & & & & & & \\
\hline 18 & 35.14 & - & & & & & & \\
\hline 19 & 34.15 & - & & & & & & \\
\hline 20 & 33.24 & - & & & & & & \\
\hline
\end{tabular}

Table 2. Analysis of variance for textural characteristics of Kradi stored at $25^{\circ} \mathrm{C}, 5^{\circ} \mathrm{C}$ and $-20^{\circ} \mathrm{C}$.

\begin{tabular}{|c|c|c|c|c|}
\hline \multirow{2}{*}{ Attribute } & \multirow{2}{*}{$\begin{array}{l}\text { df ( between packaging } \\
\text { systems) }\end{array}$} & \multicolumn{2}{|c|}{ Mean sum of squares } & \multirow{2}{*}{ F- Value } \\
\hline & & Packaging system & Time interval & \\
\hline Chewiness (at $25^{\circ} \mathrm{C}$ ) & 1 & 1089.77 & 157.91 & $72.40 * *$ \\
\hline Chewiness (at $-20^{\circ} \mathrm{C}$ ) & 1 & 6.23 & 114.73 & $15.51 * *$ \\
\hline
\end{tabular}

* * Significant at $1 \%$ level of probability

\section{Conclusion}

The effects of vacuum packaging of kradi cheese revealed that decrease in chewiness values under vacuum was slow as compared to ordinary packaging. Chewiness of product was better maintained at refrigeration temperature of $5^{\circ} \mathrm{C}$ in vacuum packaging and the product can be stored for long time at $-20^{\circ} \mathrm{C}$. Therefore vacuum packaging could be an alternative to conventional normal/open packaging for $k r a d i$ cheese in maintaining textural quality. Thus vacuum packaging can be employed for kradi cheese by producers of this traditional regional product and it can guarantee the consumers a quality product. Vacuum packaging provided an option to producer for storing the kradi cheese for longer time thereby providing economic benefit. Vacuum packaging will therefore offer manufacturers to store the product for longer time with maintained textural quality.

\section{References}

[1] Alam, T., Saha, N. C., Bharadwaj, A and Goyal, G. K., (2016). Influence of Modified Atmosphere Packaging (MAP) on textural Properties of Mozzarella cheese during refrigeration storage. Asian J. Dairy \& Food Res., 35 (2), 103-110.
[2] Bourne, M. C., (1978). Texture profile analysis. Food Technology, 32, 7: 66-72.

[3] Dimitreli, G., Exarhopoulos, S., Antoniou, K. K., Zotos, A., and Bampidis, V. A., (2017). Physicochemical, textural and sensory Properties of white soft cheese made from buffalo and cow milk mixtures, International Journal of Dairy Technology, $70,1-8$.

[4] Fox, P. F., Sweeney, P. L. H., Cogan, T. M., Guinee, T. P., (2004) Biochemistry of cheese. cheese: chemistry, physics and microbiology, volume 1, Elsevier. 765-790.

[5] Lawrence, R. C., Creamer, L. K., and Gallies, J., (1987). Texture development during cheese ripening. Journal of Dairy Science, 41 (8): 1748-1760.

[6] Mohamed, A. G and Shalaby, S. M., (2016). Texture, Chemical Properties and Sensory Evaluation of a Spreadable Processed Cheese Analogue Made with Apricot Pulp (Prunus armeniaca L.), International journal of Dairy science, 11 (2) 61-68.

[7] Olson, N. F., Johnson, M. E., (1990). Light cheese products: characteristics and economics. Journal of Food Technology, 44: 93-96.

[8] Patil, G. R., and Rao, K. J., (2006) changes in textural characteristics of paneer in ready-to-eat canned paneer curry during storage. Journal of Texture Studies, 37, 156-164. 
[9] Punoo, H. A., Patil, G. R., and Singh, R. R. B., (2018a). Textural and microstructural properties of Kradi cheese (an indigenous cheese of Jammu and Kashmir, India). International Journal of Dairy Technology, 71, 2, 372-381.

[10] Punoo, H. A, Patil, G. R., and Singh, R. R. B., (2018b). Physico-chemical and microbiological composition of Kradi cheese. Indian Journal of Dairy Science, 71 (2), 152-155.

[11] Punoo, H. A, Shafi. M, and Baba, W. N. (2017). Textural, Physico-chemical, Micro-structural and Antioxidant Properties of Soy Paneer prepared from admixtures of Skim cow milk and Soymilk. International Journal of Advanced Research in Science and Engineering, 6, 3, 387-400.

[12] Punoo, H. A. (2020). Chemical changes of kradi cheese stored at refrigeration temperature under vacuum and normal conditions, Indian J. Dairy Sci. 73 (1): 28-31.

[13] Punoo, H. A., Patil, G. R., and Singh, R. R. B. (2018c) Quantitative descriptive sensory analysis of Kradi Cheese, SKUAST Journal of Research 20 (2): 230-237.

[14] Zheng, Y., Liu, Z., and Mo, B., (2016). Texture Profile Analysis of Sliced Cheese in relation to Chemical
Composition and Storage Temperature. Journal of Chemistry, http://dx.doi.org/10.1155/2016/8690380.

[15] Dongare, S. A, Dige, Y. P., and Syed, H. M.(2019). Storage study and textural profile analysis of paneer at different temperature. Journal of Pharmacognosy and Phytochemistry, 8 (2): $864-868$

[16] VanHekken, D. L., Tunick, M. H., and Park, Y. W., (2005) Effect of Frozen Storage on the Proteolytic and RheologicalProperties of Soft Caprine Milk Cheese, J. Dairy Sci. 88: 1966-1972.

[17] Frau, F., Carate, J. N. L., Salinas, F., and Pece, N. (2021) Effect of vacuum packaging on artisanal goat cheeses during refrigerated storage, Food Sci. Technol, Campinas, 41 (2): 295-303.

[18] Mezosolis, J. A., Moohuchin, V. M., Zarate, A. S., Ronquillo, M. G., Estradaleon, R. J., Ibanez, R., Toromujica, P., Chaycanul, A. J., and Perez, E. V. B., (2020). PhysicoChemical, Sensory and Texture Properties of an Aged Mexican Manchego-Style Cheese Produced from Hair Sheep Milk, Foods, 9, 1666; doi: 10.3390/foods9111666. 